\title{
Public relations in organizations in sportsman students view: Development of management tools or healthy and friendly relations formation
}

\author{
ROZA SH. AKHMADIEVA ${ }^{1} \triangle$, MIKHAIL N. MIKHAYLOVSKY ${ }^{2}$, MARGARITA M. SIMONOVA ${ }^{3}$, SVETLANA \\ M. NIZAMUTDINOVA ${ }^{4}$, ALEXEY I. PROKOPYEV ${ }^{5}$, SOFIA SH. OSTANINA ${ }^{6}$ \\ ${ }^{1}$ Kazan State Institute of Culture, Kazan, Russian Federation \\ 2Department of Nursing Activities and Social Work, The Sechenov First Moscow State Medical University, Moscow, Russian Federation \\ ${ }^{3}$ Department of Personnel Management and Psychology, Financial University under the Government of the Russian Federation, Moscow, \\ Russian Federation \\ ${ }^{4}$ Department of Music Art, Moscow City University, Moscow, Russian Federation \\ ${ }^{5}$ Department of State and Legal Disciplines, Plekhanov Russian University of Economics, Moscow, Russian Federation \\ ${ }^{6}$ Department of Management and Business Technologies, Kazan National Research Technological University, Kazan, Russian Federation
}

\begin{abstract}
The relevance of this article is the need to study the students' understanding of public relations as a means of management. The experience of countries with a developed social sphere shows that the use of public relations in the management of social work institutions can improve the social status of social services, form a positive public opinion and, as a result, ensure the social effectiveness of services provided. The purpose of the research is to analyse students' perceptions of public relations' essence as a means of managing social services in the external environment. Research methods: as a research method, we used a questionnaire survey, which allows us to qualitatively investigate public relations in the organization through the eyes of students. Results of the research: the article considers the students' views on the means of managing social services in the external environment, reveals the role of public relations in the management of social services in the external environment in the representation of students. The novelty and originality of the research consists in the analysis of public relations as a means of management in the external environment in relation to the activities of social protection institutions in the representation of students. It is revealed that, in the view of students, public relations accumulate management tools and include: the use of various forms of communication aimed at identifying common views or interests of different groups; they contribute to the formation of partnership and friendly relations between the social service, clients and the General public; ensure the achievement of mutual understanding based on truth and full public awareness and, ultimately, form a positive public opinion and a favourable image for the social service. The essential aspects, specific features, structural and functional features and opportunities of public relations as a means of managing social services in the external environment are highlighted in the students' view. It is determined that in the views of students, the management of the social service does not have a well-thought-out concept of organizing public relations, which leads to ineffective management of the social service in the external environment and is used in social work spontaneously. Practical significance: the data obtained in this work can be used in social psychology, Economics, advertising psychology, management psychology, as well as for further theoretical development of this issue.

Keywords: Sportsman student; Public relations; Representations; Management.
\end{abstract}

\section{Cite this article as:}

Akhmadieva, R.S., Mikhaylovsky, M.N., Simonova, M.M., Nizamutdinova, S.M., Prokopyev, A.I., \& Ostanina, S.S. (2021). Public relations in organizations in sportsman students view: Development of management tools or healthy and friendly relations formation. Journal of Human Sport and Exercise, 16(3proc), S1272-S1279. https://doi.org/10.14198//hse.2021.16.Proc3.43

Corresponding author. Kazan State Institute of Culture, Kazan, Russian Federation.

E-mail: roza79.08@mail.ru

Abstract submitted to: Winter Conferences of Sports Science. Costa Blanca Sports Science Events, 22-23 March 2021. Alicante, Spain.

JOURNAL OF HUMAN SPORT \& EXERCISE ISSN 1988-5202.

(c) Faculty of Education. University of Alicante.

doi:10.14198/jhse.2021.16.Proc3.43

S1272

| 2021 | Proc3 | VOLUME 16

C 2021 University of Alicante 


\section{INTRODUCTION}

Currently, there are many tools and methods available in the Arsenal of the social service Manager for planning, organizing, motivating and controlling the internal environment of the organization in response to external changes. The only social service that can survive and function effectively in a rapidly changing environment is one that will adapt to the environment in time and possibly find ways to influence it using special management tools (Voitenko \& Komarov, 2010; Kayumova \& Morozova, 2016). Social service as an open system cannot function fully without cooperation and interaction with the external environment of the organization, since the success of social service activities depends on the forces of the external environment, which determine the General rules of the game, so they must be taken into account and used. Social service management in the external environment refers to the process of purposeful influence of the management entity in the person of the governing body or Manager on the management object in the person of the social service that provides social services, taking into account external, including environmental, factors that affect the functioning of the social service (Burganova, 2009; Mescon, Albert \& Khedouri, 1997; Zayats, 2004; Cherdymova et al., 2017a; Machnev \& Cherdymova, 2017; Lomov \& Zhuravlev, 1978; Bayanova et al., 2020). The assessment of environmental components should be based on the allocation of funds (i.e., those components that the organization can use to achieve its own goals) and conditions, components of the external environment that the organization cannot use to achieve goals (Zaitsev, 2011; Cherdymova et al., 2017b; Mikheev, 2001; Kayumova, 2016). Public relations is a management tool that uses various forms of communication aimed at identifying common views or interests of different groups, promotes partnership and friendly relations formation between the social service, clients and the General public, ensures mutual understanding based on truth and full public awareness, and ultimately forms a positive public opinion and a favourable image for the social service (Ponomarev, 2008; Abramov, 2012; Barezhev \& Malkevich, 2010; Kuznetcov, 2007; Olkhovaya et al., 2019; Kovalchuk, 2009; Kondratiev \& Abramov, 2009; Bayanova et al., 2019). Becoming a subject of management activity, having broad economic independence in its production and economic activities, the social service should form a management system that could provide them with a sufficient degree of functioning efficiency, competitiveness and a stable position in the market of social services. This task is carried out by using appropriate management tools in management practice (Frolovsky, 1997; Khashchenko, 1988; Tolochek, 1992).

Thus, in the management of social services, it is important to take into account all the factors of the external environment of the organization and build management strategies accordingly (Lyashenko, 1995; Tatarinova, 2004; Bolotova, Zhukov \& Petrovskaya, 2008; Doblaev, 2002). If there is a change in the direct impact factors, the social service can respond in two ways: either to initiate a policy of active adaptation, or to implement a policy of counteraction. The social service has to adapt its internal variables - goals, tasks, structure, technology, organization personnel, etc. - to the factors of indirect impact. Public relations is a comprehensive tool for managing social services in the external environment and actualizes all other management tools, including social communication, image, social partnership and positioning. In this regard, it is necessary to describe the role of public relations in the management of social services in the external environment in more detail.

\section{MATERIALS AND METHODS}

The study included a number of stages. At the first stage, a survey was conducted of Humanities students and students studying at economic faculties who were interning at the centre for social services in order to identify ideas about the current state of using public relations as a means of managing the centre for social services of citizens. The sample was targeted in nature. When conducting a questionnaire survey, it was 
assumed that the process of registration reveals the subjective views, opinions and assessments of students, which are subject to fluctuations, the effects of the survey conditions and other circumstances. To minimize data distortion associated with these factors, the survey was conducted in a short time.

The questionnaire included three units. The first unit was devoted to introducing students to the concept of public relations. The second section of the questionnaire included an assessment of the practice in using the leading areas of public relations when working with clients, commercial structures, and media structures. The third section covered the issues of public relations in working with sponsors. The fourth section of the questionnaire concerned General information about the Respondent.

In the pilot study, we were interested in the students' understanding of public relations in the management of the social service centre's activity. It was found that the opinion of students was divided as follows: $61 \%$ of students of Humanities answered in the affirmative, $23 \%$ of respondents were at a loss for an answer, and $16 \%$ did not know what it was. The answers of students studying at the faculty of Economics are somewhat compared and distributed as follows: $71 \%$ said that they knew about the organization of public relations in the organization's activities, $81 \%$ were difficult to answer, and $11 \%$ had no idea about public relations in the organizations' activities.

Further, the research task was to identify students' knowledge and understand the current state of using public relations as a management tool.

\section{RESULTS AND DISCUSSION}

The conducted research clarified a number of interesting questions related to the students' understanding and evaluation of the practice in using leading areas of public relations, such as: working with private clients, working with a commercial structure, working with structural divisions of the media. So, when answering a question: What, in Your opinion, is the activity of public relations?, the responses of students were distributed as follows: $62 \%$ of students of Humanities pointed to the formation of a positive image of the social service centre institution in the eyes of the public, $25 \%$ pointed to the promotion of the social service centre's activity and $13 \%$ to the advertising of social services. Among students of the faculty of Economics, only $39 \%$ indicated the formation of a positive image of the institution in the eyes of the public, $58 \%$ of respondents noted the promotion of the social service centre's activity, and $3 \%$ of students noted the advertising of social services as the main activity. As you can see, the opinions of students of Humanities and students of the faculty of Economics differ radically. This indicates that these students have different information about the management activities of the administration of social service centres.

The next question in the questionnaire was to find out what areas of public relations work in the social service. Respondents were asked to evaluate the activities of the centre's management in four areas: working with clients, working with a commercial structure, working with government authorities, and working with the media. As an additional option, respondents could indicate a different line of work that they believe was taking place in their social service. The answers were as follows. Speaking about working with clients, Humanities students $(81 \%)$ noted that this type of activity was carried out regularly, only $9 \%$ of respondents chose the option - from time to time, and 10\% found it difficult to answer. According to students of the faculty of Economics, working with clients was carried out regularly in $100 \%$ of cases. Describing the work of the social services centre with the media, $39 \%$ of Humanities students said that it was rare; answer- from case to case, chose $33 \%$ of the respondents; $20 \%$ said that the work on this direction was conducted regularly; $8 \%$ were difficult to answer. The responses of students of the faculty of Economics were distributed as follows: $37 \%$ 
found it difficult to answer; $19 \%$ indicated that work in this area was carried out case-by-case; $10 \%$ of respondents noted the answer - rarely, and $34 \%$ believed that work with the media was carried out constantly. The respondents did not identify any other areas of public relations. Summing up the above-mentioned, one can sum up some results. Evaluating the work of the social service centre for public relations, the majority of students $(89 \%)$ identified such a direction as working with clients. A similar picture can be seen when evaluating interaction with state authorities and state structures. Evaluating the work with a commercial structure, the majority of students said that such activities were carried out in the social service centre rarely $(48 \%)$ or not at all (52\% of respondents). However, among students of the Humanities, the percentage of those who found it difficult to answer was quite large. This fact indicates that students of the Humanities have less information about this area of public relations in the social service.

Thus, speaking about the contacts of the social service centre with the media, the students unanimously noted that such work, in their opinion, was carried out case-by-case. The results obtained allow us to state that the work on public relations in the social service centre is narrowly focused, directly related to the main professional activities of employees and the management apparatus.

The next section of the study was devoted to finding out what forms of public relations organization were used, in the opinion of students, in the management of social services in each of the indicated areas. The results were distributed as follows. When working with clients, $68 \%$ of Humanities students noted holidays and festive events, $21 \%$ of students indicated articles in Newspapers and $11 \%$ found it difficult to answer. The opinion of students of the faculty of Economics was distributed as follows: $72 \%$ noted holidays and festive events, $10 \%$ pointed to publications in Newspapers and $12 \%$ were difficult to answer. Thus, the opinions of students on this issue actually coincide. The study showed that $72 \%$ of clients paid special attention to working with real clients; the social service centre paid attention to working with potential clients, according to $21 \%$ of respondents, and $7 \%$ of the surveyed Humanities students noted working with a reference group for clients. The opinion of students of the faculty of Economics was distributed as follows: $81 \%$ noted working with real clients; $9 \%$ indicated working with potential clients and $10 \%$ noted a reference group for clients.

In this regard, the students were asked: does the social service where they were interning have a special plan for organizing public relations? Students' responses were distributed as follows: $71 \%$ do not know about the existence of such a plan; $17 \%$ of students believe that there is no such plan; $12 \%$ believe that there is such a plan The received answers allow us to state that there is no purposeful activity on organizing public relations in the social service centre, where students were interned. To the question: How often is information given to the press about the activities of the social service in which they were trained? The respondents' opinions were distributed as follows: the first place was taken by the answer: the answer is not given at all; the second place was taken by the answer: once a year, the third place was taken by the answer: once every six months. No one chose the answer: once every three months. These responses indicate that in the students' views, the management of the social service does not have a well-thought-out concept of organizing public relations, which leads to ineffective management of the social service in the external environment.

At the end of the survey, the respondents were asked to evaluate the level of public relations' organization in the social service centre where they were trained, in general. For this purpose, we asked the respondents: what level do they think is the use of forms and methods of public relations in the work of the social service in which they were trained? The results of the responses were distributed as follows: students of Humanities in the first place put the average level; the second place was occupied by the answer - high and the answer - low level was in the third place. Students of the faculty of Economics believe the same. An important feature 
of properly organized PR is that this work should be aimed not so much at short-term results, but at achieving long-term goals.

The diversity of opinions of students who were interning in social service centres required an assessment of the state of public relations organization as a means of management in the external environment by the administration of these centres. We were interested in the management's opinion on how public relations were used in the management of the social service centre, and how the management's activities in this area were organized. In connection with the above-mentioned, a survey was conducted of the social service centre's Director and the heads of the centre's departments. The sample was continuous in nature. The survey shows that the priority in public relations is working with real clients. Work with potential clients and reference groups for clients is practically not carried out, everything is limited to accepting applications for social services. This situation is explained, first, by the lack of personnel and the reluctance of people to contact the social service. The centre's specialists are primarily focused on meeting the standards for the reception of citizens, completed cases depending on the direction of work, while the heads of structural divisions coordinate the work and monitor the completion of cases. The next section of the survey concerned the use of forms and methods of organizing public relations in the management of social services. The results of the responses showed that they were intermittent and haphazard in nature, and most employees were not aware of the possible use of forms and methods of public relations. Feedback from the population is provided, but mostly it is complaints or thanks and congratulations on holidays. Managers of structural divisions of social service centres have little knowledge of the forms and methods of organizing public relations and do not use them in their practical activities. The next section of the interview concerned working with a commercial structure. According to the study, this work is being carried out, but it is at a low level. Almost all respondents admit that the work with the commercial structure is carried out, but it is unstable and not clearly structured. As for the organization of public relations with the mass media (radio, Newspapers, television), the situation is somewhat different. Clarification of the nature of interaction between social services and the media was not an unimportant issue. Relations with the media are an essential component of public relations. Public opinion is mainly formed by what people read in the press, hear on the radio or see on television, so cooperation with the media should be given special attention. Work with the state structure is carried out systematically, but it is not always possible to lobby the interests of the social service. During the survey, we were interested in the question: How does public relations affect the activities of the social service? Is public relations a means of managing social services in the external environment? Respondents' opinions agreed that public relations really had a positive impact on the work of the centre. Thus, the study showed that Department managers considered it important to organize public relations in social service centres, but unfortunately, this activity in the management of social services was poorly organized and was random. Thus, students' perceptions of the work of public relations in social service centres largely coincide with the opinion of the centres' management.

In modern conditions, public relations as a means of managing social services in the external environment should be aimed at fully explaining to the public of the existing socio-economic problems, creating a positive image of the institution of social work, ensuring a favourable social atmosphere in the external environment in society, for the implementation of the social programs provided. It is clear from the research that most managers of the social service centre believe that the organization of public relations in the management of their service is at an average level. Students also note that this is a whole area of management activity that has not yet been widely studied and is used in social work spontaneously. Therefore, some shortcomings in the work are obvious. In particular, during the survey, the heads of structural departments of the social service centre expressed a number of wishes and suggestions for improving this work: when organizing public relations with clients, it is necessary to attract potential clients and organize work with a reference group for 
clients; for organizing public relations with sponsors, it is important to focus on a purposeful working with sponsors. Research is needed to find a potential sponsor. It is necessary to determine which characteristics of the event held in social service centres correspond to the interests of potential sponsors. Working with a sponsor means constant communication. The ultimate aerobatics of working with a sponsor is when the sponsor is involved in the work of the social service, is constantly interested in what is happening, and does not become indifferent to all subsequent events. It is quite difficult to find a sponsor willing to pay for even part of the event. It is necessary to regularly send letters to sponsors describing the event, conduct telephone conversations, as well as organize personal meetings - the key to establishing the necessary contacts. It is necessary to ensure constant work with the media. To organize all this work, respondents consider it necessary to allocate a staff unit that will be engaged in organizing public relations in social service centres. From the conducted research, it becomes clear that, in the view of students, the social service tries to apply public relations in its management activities; however, almost all attention is paid to real clients of the social service, which indicates a large share of the audience not covered.

\section{CONCLUSION}

Summarizing the above-mentioned, it should be noted that the experience of countries with a developed social sphere shows that the use of public relations in the management of social work institutions can improve the social status of social services, form a positive public opinion and, as a result, ensure the social effectiveness of services provided.

Meanwhile, practice shows that not all social services have the technology to organize public relations. Many managers of social services underestimate the role of public relations in the management of the organization, do not know the technology of establishing contacts in the external environment, and do not know the forms and methods of public relations. Ultimately, this reduces the effectiveness of the social service as a whole, reduces its status in society and does not contribute to the formation of a positive public opinion. As a result, the activities of the social work institution are poorly covered in the mass media, and the population is poorly informed about the activities of the social service. The public is not well aware of the organization's innovations and procedures, which complicates the work of the institution. Ultimately, this creates a low level of public confidence in individual social institutions and, in particular, in social services.

At the same time, when planning further development of social work institutions, it is necessary to take into account the current state of society. If in the years of Soviet power, the management of social work institutions was a function of the administrative command system and the formation of the image of the institution in public opinion did not exist, today the task of forming public relations in the management of social services in the external environment becomes one of the pressing tasks of modern management. Now, when managing social work institutions in the external environment, it is necessary to clearly understand the goals and mission of the organization and be ready for a broad dialogue with the public.

\section{REFERENCES}

Abramov, R.N. (2012). Public Relations. Moscow: Publishing house "KnoRus". https://doi.org/10.15216/9785406016015

Barezhev, V.A. \& Malkevich, A.A. (2010). Organizing and conducting PR campaigns. Saint Petersburg: Piter. 
Bayanova, A.R., Sivova, I.V., Kamasheva, Y.L., Popova, O.V., Semyanov, E.V., Shagieva, R.V. \& Yusupov, I.M. (2020). Student online services consumption: Routine practices or mistrust to digital service? Contemporary Educational Technology, 11(1), 47-54. https://doi.org/10.30935/cet.641767

Bayanova, A.R., Vodenko, K.V., Sizova, Z.M., Chistyakov, A.A., Prokopyev, A.I. \& Vasbieva, D.G. (2019.) A philosophical view of organizational culture policy in contemporary universities. European Journal of Science and Theology, 15(3), 121-131.

Bolotova, A.K., Zhukov, Yu.M. \& Petrovskaya, L.A. (2008). Social communications. Moscow: Gardariki. Burganova, A.A. (2009). Management theory. Moscow: INFRA-M.

Cherdymova, E.I., Borisova, M.O., Peremyshlina, E.S. \& Peshnova, E.I. (2017a). Professional adaptation of employees as a social factor of organization's effective activity. Cooperation and entrepreneurship: status, problems and prospects. Collection of scientific papers of the International conference of young scientists, postgraduates, undergraduates and students, pp. 118-120.

Cherdymova, E.I., Kuznetcov, V.A., Machnev, V.Y., Solovova, N.V., Sarbaeva, I.Y. \& Masalimova, A.R. (2017b). Eco-vocational consciousness formation model of a specialist in modern mega polis. Eurasian Journal of Analytical Chemistry, 5, 521-531. https://doi.org/10.12973/ejac.2017.00187a

Doblaev, V.L. (2002). Organizational behavior. Moscow: EKMOS.

Frolovsky, S.Yu. (1997). Three-Dimensional model of effective characteristics of managerial activity: empirical validation. Bulletin of the Baltic Pedagogical Academy, 12, 95-102.

Kayumova, L.R. (2016). Formation of the noxologic educational environment in elementary school: Application of moderation technology. Mathematics Education, 11(4), 779-786.

Kayumova, L.R.\& Morozova, M.A. (2016). Using the technology of critical thinking development (CTD) as a means of forming competencies of students majoring in "life safety". International Journal of Environmental and Science Education, 11(8), 2113-2122.

Khashchenko, V.A. (1988). Research of the collective subject of management. Joint activity: methodology, theory, practice, 1, 88-98.

Kondratiev, E.V. \& Abramov, R.V. (2009). Public relations. Moscow: Academic project.

Kovalchuk, A.S. (2009). Fundamentals of image and business communication. Rostov on Don: Phoenix. Kuznetcov, V.F. (2007). Public Relations: Theory and technology. Moscow: Aspect Press.

Lomov, B.F. \& Zhuravlev, A.L. (1978). Psychology of management. Moscow: Znanie.

Lyashenko, A.I. (1995) Organization and management of social work in Russia. Moscow: Nauka.

Machnev, V.Ya. \& Cherdymova, E.I. (2017). Essence of differences between eco-professional, environmental and professional training of a specialist. Current issues of human ecology: social aspects, collection of scientific articles of participants of the International scientific and practical conference, pp. 7-12.

Mescon, M.Kh., Albert, M. \& Khedouri, F. (1997). Fundamentals of management. Moscow: Delo.

Mikheev, V.A. (2001). Fundamentals of social partnership: theory and policy. Moscow: Examen.

Olkhovaya, T.A., Cherdymova, E.I., Merculova, L.V., Manakova, O.S., Sukhodolova, E.M., Laptev, A.A. \& Popova, O.V. (2019). Development features of students communicative focus. Modern Journal of Language Teaching Methods, 1(9), 78-89.

Ponomarev, N.F. (2008). Public Relations: socio-psychological aspects. Saint Petersburg: Peter.

Tatarinova, G.N. (2004). Management of public relations. Saint Petersburg: Peter.

Tolochek, V.A. (1992). Triad of management and management style. Sociological research, 1, 121-125.

Voitenko, A.I. \& Komarov, E.I. (2010). Organization, management and administration in social work. Moscow: INFRA-M.

Zaitsev, D.V. (2011). Organization, management and administration in social work. Moscow: Publishing and trading Corporation "Dashkov and Co".

Zayats, O.V. (2004). Organization, administration and management in social work. Moscow: INFRA-M. 


\section{(c) $(1) \Theta$}

This work is licensed under a Attribution-NonCommercial-NoDerivatives 4.0 International (CC BY-NC-ND 4.0). 